\title{
SISTEM INFORMASI PENDISTRIBUSIAN BANTUAN PERANTAU MINANG MENGGUNAKAN PHP DAN MYSQL
}

\author{
Rahimullaily ${ }^{1)}$, Suardinata ${ }^{2)}$, Eka Yulia ${ }^{3)}$ \\ ${ }^{1,2,3}$ Sistem Informasi, STMIK Indonesia Padang \\ email: rahimullaily@stmikindonesia.ac.id, suardinata@stmikindonesia.ac.id, ekayulia23@gmail.com
}

\begin{abstract}
Biro Administrasi Pembangunan dan Kerjasama Rantau (BAPKR) merupakan salah satu unit kerja mandiri di lingkungan sekretariat daerah Provinsi Sumatera Barat. BAPKR mempunyai tugas pokok dalam menyelenggarakan perumusan bahan kebijakan umum dan koordinasi, fasilitasi, pelaporan, evaluasi dan pengendalian administrasi pembangunan dan kerjasama rantau. Pencatatan data pendistribusian bantuan perantau di BAPKR menggunakan Microsoft Excel. Permasalahan yang terjadi adalah keterlambatan dalam pembuatan laporannya, keamanan data tidak terjamin, dan sering terjadi data ganda dalam pencarian data bantuan. Metode penelitian yang dilakukan adalah melakukan observasi, wawancara dan pemberian kuisiner kepada pegawai, serta menggunakan metode System Development Life Cycle (SDLC). Penelitian ini menghasilkan program aplikasi untuk mengolah data pendistribusian bantuan perantau Minang yang keamanan datanya terjamin dan tidak terjadinya data ganda sehingga menghasilkan laporan pendistribusian perantau Minang yang akurat.
\end{abstract}

\section{Keywords: Sistem Informasi, Pendistribusian Bantuan Perantau Minang}

\section{PENDAHULUAN}

Dengan berkembangnya ilmu pengetahuan dan teknologi pada saat ini memberikan kemudahan pada dunia kerja, di mana teknologi komunikasi dan informasi menjadi penunjang yang sangat penting dalam pelaksanaan setiap kegiatan. Biro Administrasi Pembangunan dan Kerjasama Rantau (BAPKR) merupakan suatu instansi pemerintahan yang memiliki kekuasaan untuk menciptakan kualitas informasi yang baik. Sebagaimana juga tercantum dalam visi dan misi BAPKR yaitu Terwujudnya Masyarakat Sumatera Barat Madani yang adil, Sejahtera dan Bermartabat. Untuk mewujudkan sasaran dan tujuan dari visi dan misi itu diperlukan beberapa peningkatan dalam pengolahan data bantuan perantau agar terciptanya pelayanan yang baik.

Dalam kegiatan kerja di BAPKR staf/pegawai mengolah data pendistribusian bantuan perantau Minang menggunakan Microsoft Excel. Staf/pegawai mengumpulkan data pendistribusian bantuan perantau Minang yang telah diserahkan oleh masing-masing staf/pegawai kantor wali nagari dengan cara mencatat ulang ke Microsoft Excel dalam bentuk sheet, sehingga membutuhkan waktu yang lebih lama. Mengingat banyaknya perantau yang akan memberikan bantuan, dan pencatatan ulang data membutuhkan waktu yang lama, sering terjadi data ganda, akibatnya staf/pegawai BAPKR harus menyeleksi ulang data tersebut. Pembuatan laporan bantuan perantau Minang masih belum memiliki sistem informasi yang baik, karena belum memiliki sistem informasi berbasis database.

Sistem merupakan suatu kesatuan yang terdiri dari dua atau lebih komponen atau subsub sistem yang saling terjalin antara satu dengan yang lainnya untuk mencapai suatu tujuan (Hanif Al Fatta, 2007:3). Informasi merupakan data yang telah diolah menjadi sebuah bentuk yang berarti bagi penerimanya dan bermanfaat dalam pengambilan keputusan saat ini atau saat mendatang (Abdul Kadir, 2013:45). Menurut Abdul Kadir (2013:8) bahwa "sistem informasi merupakan sejumlah komponen (manusia, komputer, teknologi informasi dan prosedur kerja), ada sesuatu yang diproses (data menjadi informasi) dan dimaksudkan untuk mencapai suatu sasaran atau tujuan". Dapat disimpulkan bahwa sistem informasi terdiri dari kumpulan komponen yang saling berhubungan antara komponen satu dengan komponen lainnya untuk menghasilkan informasi yang bermanfaat.

Database adalah sumpulan dari data yang saling berhubungan satu dengan yang lainnya, tersimpan di perangkat keras komputer dan digunakan perangkat lunak untuk memanipulasinya (Jogiyanto HM, 2005:217). 
Dengan adanya permasalahan yang ada di atas maka penulis membangun sistem dalam mengolah data pendistribusian bantuan perantau Minang dengan menggunakan pemrograman PHP dan MySQL sehingga dengan adanya data pendistribusian bantuan perantau Minang yang valid tentu membuat staf/pegawai BAPKR dapat mengetahui data pendistribusian bantuan perantau Minang yang tepat, akurat dan pekerjaan staf/pegawai BAPKR lebih optimal.

Bantuan perantau Minang merupakan bantuan yang diberikan oleh perantau untuk nagari dalam rangka membantu nagari dalam meningkatkan kesejahteraan masyarakat. Sistem informasi pendistribusian data bantuan perantau Minang di BAPKR merupakan suatu sistem yang dirancang untuk melakukan pengolahan data pendistribusian bantuan perantau Minang menggunakan database MySQL. MySQL merupakan penyimpanan data yang fleksibel dan cepat untuk diakses. Jenis database ini sangat popular dan dan digunakan pada banyak website di internet sebagai bank data. MySQL menggunakan $S Q L$ dan bersifat free (gratis atau tidak perlu membayar untuk menggunakannya). Selain itu, MySQL dapat berjalan di berbagai platform, antara lain linux dan windows (M. Leo Agung, 2011:288). Sistem informasi yang dirangcang ini dibuat dengan menggunakan bahasa pemrograman PHP.

PHP merupakan salah satu bahasa pemrograman yang berjalan dalam sebuah webserver dan berfungsi sebagai pengolah data pada sebuah server. Untuk membuat website yang dinamis dan mudah untuk diupdate setiap saat dibrowser, dibutuhkan sebuah program yang mampu mengolah data dari komputer client atau dari komputer server itu sendiri sehingga mudah dan nyaman untuk disajikan dibrowser (M. Leo Agung, 2011:216).

\section{METODE PENELITIAN}

Untuk mencapai tujuan dalam penelitian terutama dalam mengumpulkan data-data serta ilmu pengetahuan untuk mendukung proses penelitian ini dilakukan metode antara lain:

a. Observasi

Penulis melakukan pengamatan di BAPKR dan mendapatkan data melalui wawancara dan pemberian daftar pertanyaan (kuisioner) kepada staf/pegawai BAPKR. b. MenerapkanSystem Development Life Cycle (SDLC)

1) Perencanaan sistem

Dilakukan oleh penulis dengan mempelajari konsep sistem yang diinginkan oleh pihak manajemen, apakah sistem baru tersebut realistis.

2) Analisis Sistem

Analisa data yang diperoleh saat melakukan perencanaan sistem ke BAPKR. Penulis menemukan kekurangan pada sistem yang digunakan dalam pengolahan data pendistribusian bantuan perantau Minang. Kekurangannya tersebut antara lain: (a) membutuhkan waktu karena staf/pegawai BAPKR mengumpulkan data pendistribusian bantuan perantau Minang yang telah diserahkan oleh masing-masing staf/pegawai kantor wali nagari dan mencatat ulang ke Microsoft Excel, (b) penyajian laporan pendistribusian bantuan perantau Minang kurang efektif dan tidak akurat karena pembuatan laporan belum memiliki sistem informasi berbasis database, (c) sering terjadi data ganda dalam menginputkan data pendistribusian bantuan perantau Minang karena belum adanya pengelompokkan data berdasarkan indeks. Penulis memberikan solusi dalam menutupi kekurangan sistem yang digunakan tersebut, yaitu dengan membuat atau membangun sistem informasi pendistribusian bantuan perantau Minang menggunakan PHP dan MySQL.

3) Desain Sistem

Desain sistem merupakan pendekatan awal untuk menyelesaikan masalah dipilih. Selama perancangan sistem, struktur keseluruhan diputuskan. Arsitektur sistem adalah suaru cara pengorganisasian sistem ke dalam apa yang dinamakan subsistemsubsistem (Adi Nugroho, 2005:203). Kegiatan yang dilakukan penulis pada tahap ini adalah merancang struktur database mulai dari nama database, nama tabel dan atribut yang dibutuhkan dalam sistem informasi pendistribusian bantuan perantau Minang.

Desain Hierarchy Plus Input Process Output (HIPO) ditunjukkan Gambar 1. Gambar 1 menunjukkan terdapat 15 buah fungsi di dalam sistem informasi 
pendistribusian bantuan perantau Minang sebagai berikut:

1. Fungsi dengan nomor 1.0 atau fungsi entri, fungsi 2.0 atau fungsi proses, fungsi 3.0 atau fungsi laporan merupakan tingkatan yang tertinggi.

2. Fungsi dengan nomor 1.1 atau fungsi perantau, fungsi 1.2 atau fungsi nagari, fungsi 1.3 atau fungsi bantuan, fungsi 1,4 atau fungsi potensi merupakan fungsi di bawah fungsi 1.0 atau fungsi entri.

3. Fungsi dengan nomor 2.1 atau fungsi transaksi merupakan fungsi di bawah fungsi 2.0 atau fungsi proses.

4. Fungsi dengan nomor 3.1 atau fungsi laporan pendistribusian bantuan per periode uang dan barang, fungsi 3.2 atau fungsi laporan pendistribusia bantuan per nagari uang dan barang, fungsi 3.3 atau fungsi laoran pendistribusian bantuan berdasarkan nama perantau uang dan barang merupakan fungsi di bawah fungsi 3.0 atau fungsi laporan.

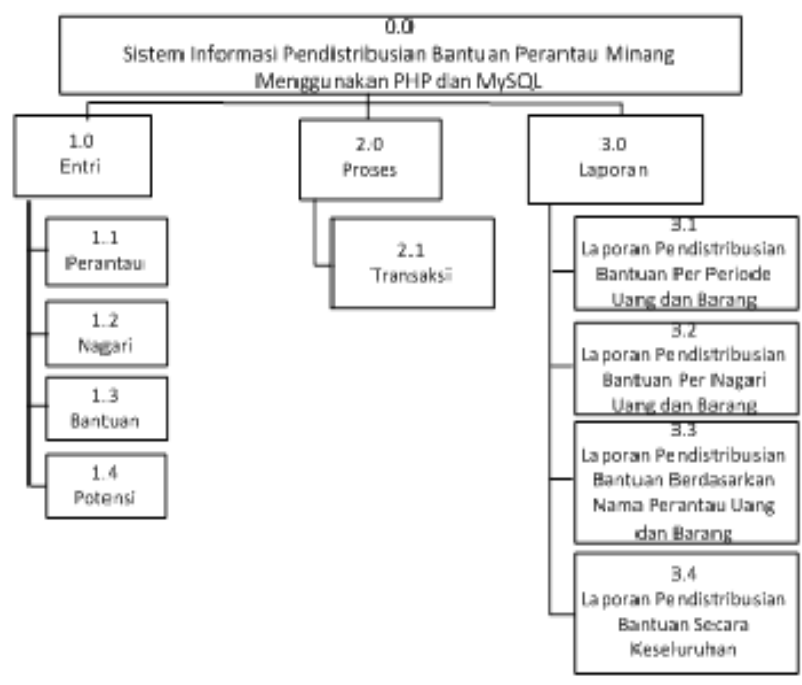

Gambar 1. Desain HIPO

Desain Context Diagram (CD) ditunjukkan pada Gambar 2. Gambar 2 menunjukkan bahwa sistem menerima data perantau, data nagari, data bantuan, data potensi dari entitas operator BAPKR. Selanjutnta, sistem menghasilkan laporan pendistribusian bantuan per periode uang dan barang, laporan pendistribusian bantuan per nagari uang dan barang, laporan pendistribusian bantuan berdasarkan nama perantau uang dan barang, laporan pendistribusian bantuan secara keseluruhan yang telah di telah disetujui kepada entitas kabag kerjasama rantau. Selajutnya, sistem menghasilkan laporan pendistribusian bantuan per periode uang dan barang, laporan pendistribusian bantuan per nagari uang dan barang, laporan pendistribusian bantuan berdasarkan nama perantau uang dan barang, laporan pendistribusian bantuan secara keseluruhan yang telah disahkan kepada entitas kepala BAPKR.

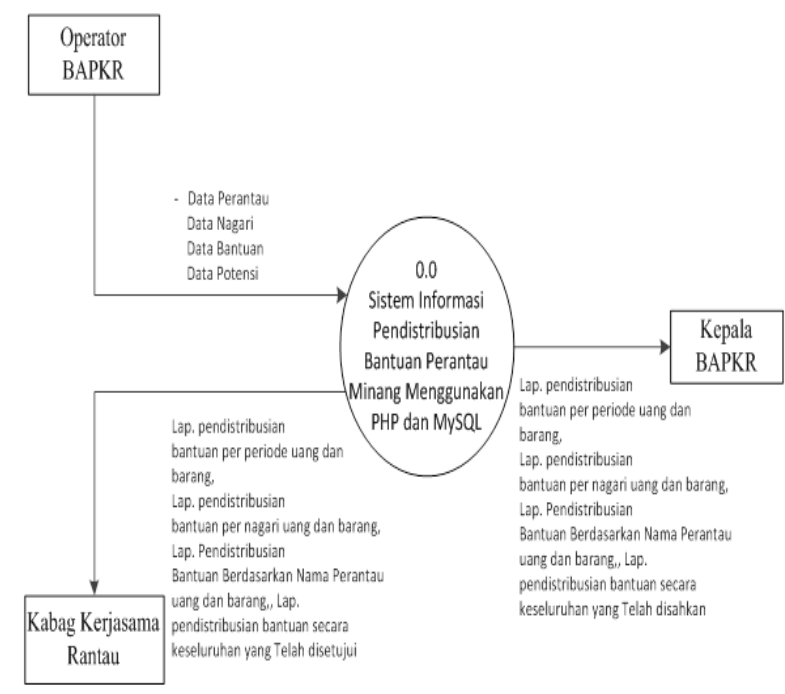

Gambar 2. CD

Desain Data Flow Diagram (DFD) ditunjukkan pada Gambar 3.

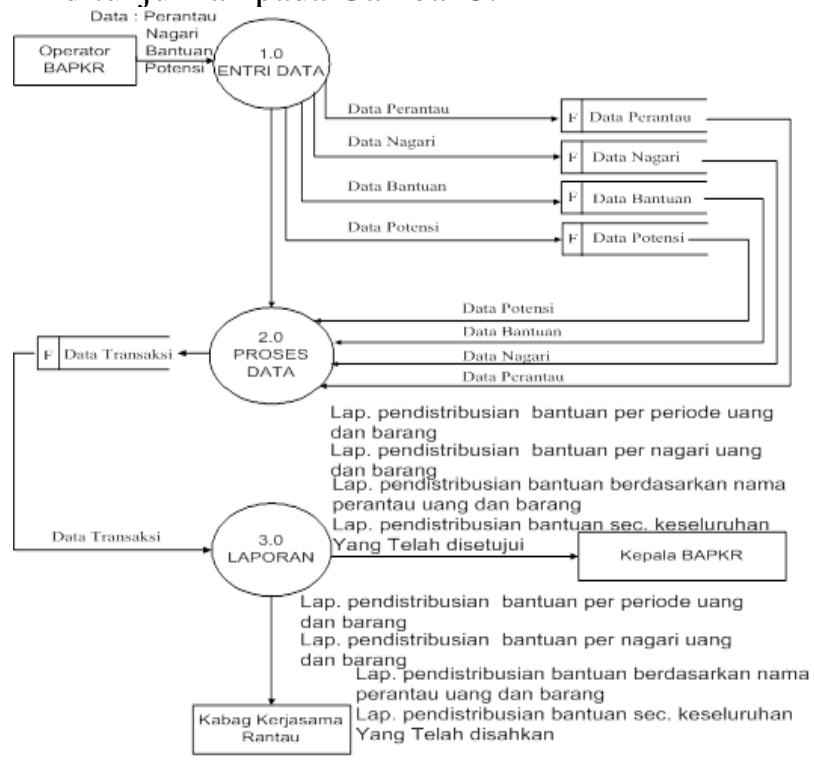

Gambar 3. DFD

Gambar 3 menunjukkan sistem 1.0 menerima entri data perantau, nagari, bantuan, potensi dari entitas operator BAPKR. Sistem 1.0 menyimpan data 
perantau, nagari, bantuan, potensi kemudian diteruskan ke sistem 2.0 untuk dilakukan proses data transaksi. Sistem 2.0 menyimpan data transaksi dan menyalurkan data ke sistem 3.0 untuk menghasilkan laporan pendistribusian bantuan per periode uang dan barang, laporan pendistribusian bantuan per nagari uang dan barang, laporan pendistribusian bantuan berdasarkan nama perantau uang dan barang, laporan pendistribusian bantuan secara keseluruhan yang telah disetujui kepada entitas kepala BAPKR, laporan pendistribusian bantuan per periode uang dan barang, laporan pendistribusian bantuan per nagari uang dan barang, laporan pendistribusian bantuan berdasarkan nama perantau uang dan barang, laporan pendistribusian bantuan secara keseluruhan yang telah disahkan kepada entitas kabag kerjasama rantau.

Desain Entity Relationship Diagram (ERD) ditunjukkan pada Gambar 4.

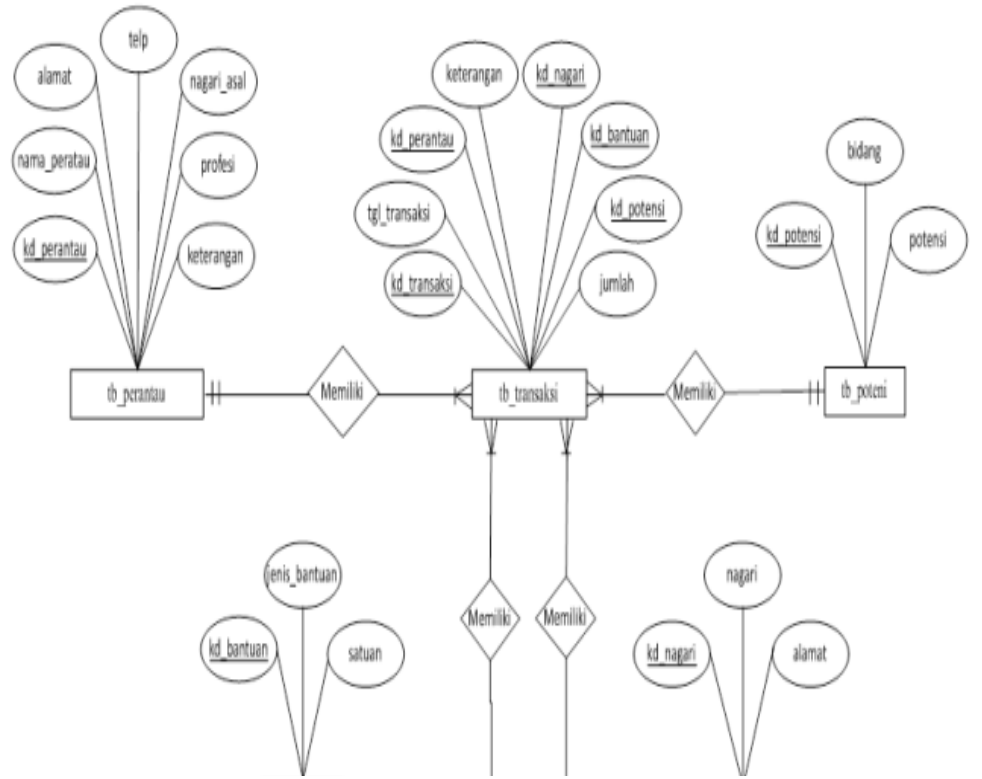

Gambar 4. ERD

Keterangan Gambar 4:

a. Entitas perantau terdiri dari atribut kd_perantau, nama_perantau, alamat, telp, nagari_asal, profesi, keterangan berelasi dengan entitas transaksi yang terdiri dari atribut kd_transaksi, tgl_transaksi, kd_perantau, keterangan, kd_nagari, kd_bantuan, kd_potensi, jumlah melalui atribut primary key kd_perantau. b. Entitas nagari terdiri dari atribut kd_nagari, nagari, alamat berelasi dengan entitas transaksi yang terdiri dari atribut kd_transaksi, tgl_transaksi, kd_perantau, keterangan, kd_nagari, kd_bantuan, kd_potensi, jumlah melalui atribut primary key kd_nagari.

c. Entitas bantuan terdiri dari atribut kd_bantuan, jenis_bantuan, satuan berelasi dengan entitas transaksi yang terdiri dari atribut kd_transaksi, tgl_transaksi, kd_perantau, keterangan, kd_nagari, kd_bantuan, kd_potensi, jumlah melalui atribut primary key kd_bantuan.

d. Entitas potensi terdiri dari atribut kd_potensi, bidang, potensi berelasi dengan entitas transaksi yang terdiri dari atribut kd_transaksi, tgl_transaksi, kd_perantau, keterangan, kd_nagari, kd_bantuan, kd_potensi, jumlah melalui atribut primary key kd_potensi.

e. Entitas transaksi terdiri dari atribut kd_transaksi, tgl_transaksi, kd_perantau, keterangan, kd_nagari, kd_bantuan, kd_potensi, jumlah melalui atribut primary key kd_transaksi.

4) Implementasi

Kegiatan yang dilakukan penulis pada tahap ini adalah melakukan implementasi sistem informasi pendistribusian bantuan perantau Minang berupa sosialisasi program ke BAPKR.

\section{HASIL DAN PEMBAHASAN}

a. Form Login

Sebelum masuk ke dalam menu utama maka tampil form login. Form login Sistem Informasi Pendistribusian Bantuan Perantau Minang ditunjukkan pada Gambar 5.

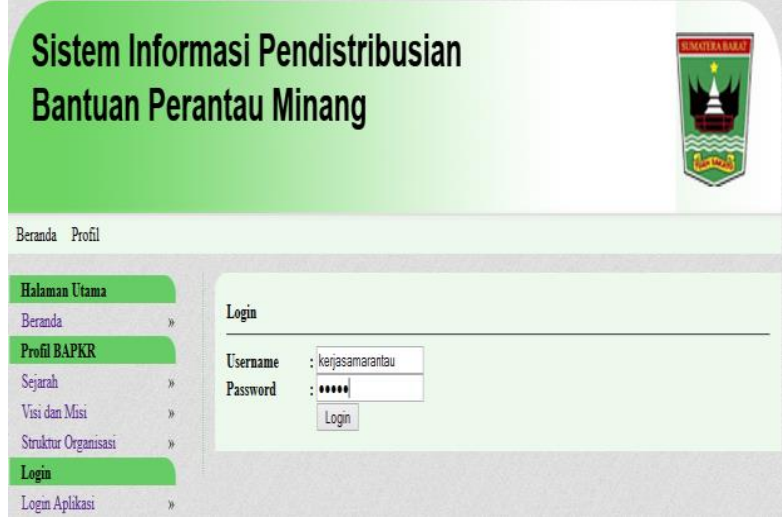

Gambar 5. Form Login 
b. Menu Utama

Menu utama Sistem Informasi Pendistribusian Bantuan Perantau Minang ditunjukkan pada Gambar 6.

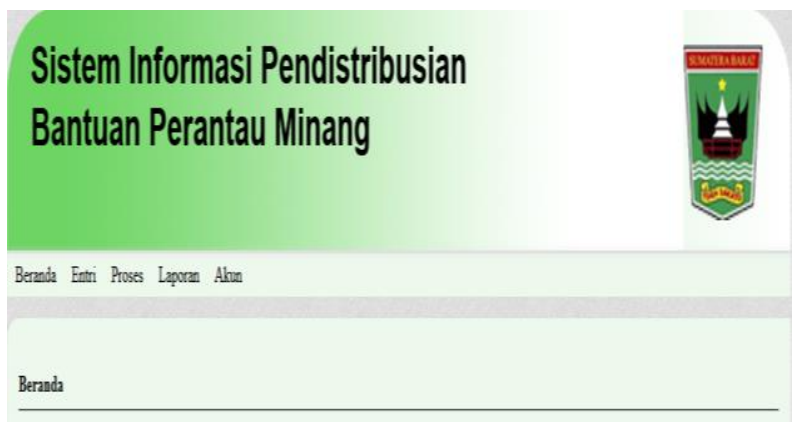

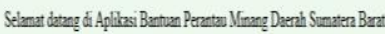

\section{Gambar 6. Menu Utama}

c. Entri

Menu entri berisi tentang 4 form entri data, yaitu:

1) Entri Data Perantau

Form Entri Data Perantau berfungsi sebagai sarana untuk menginputkan data perantau, ditunjukkan pada Gambar 7.

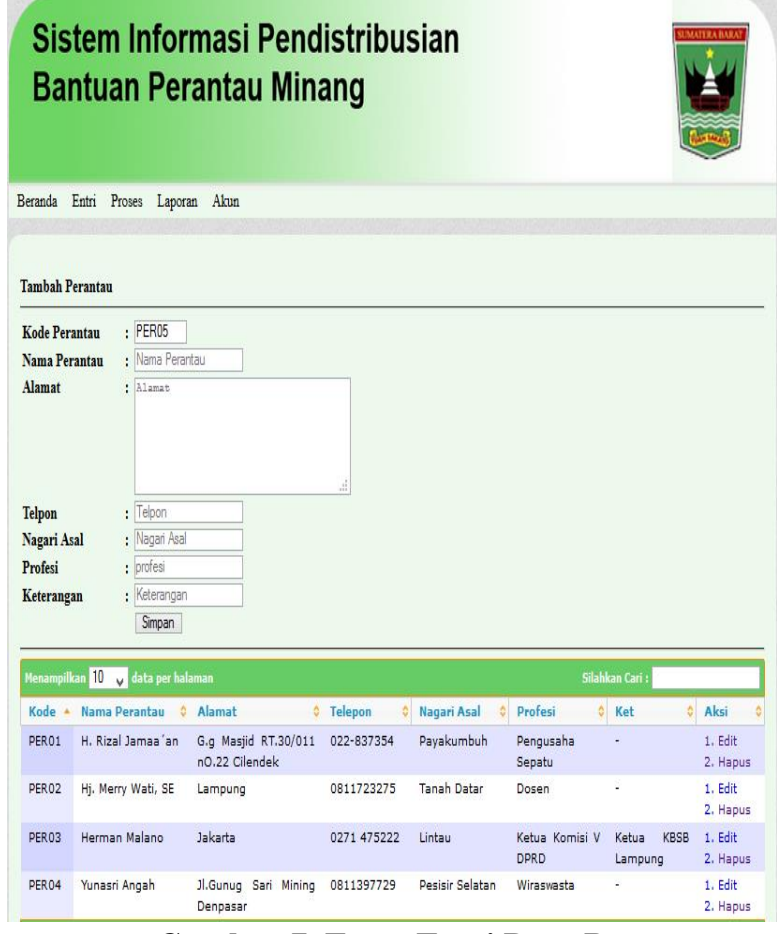

Gambar 7. Form Entri Data Perantau

2) Entri Data Nagari

Form Entri Data Nagari berfungsi sebagai sarana untuk menginputkan data nagari, ditunjukkan pada Gambar 8.

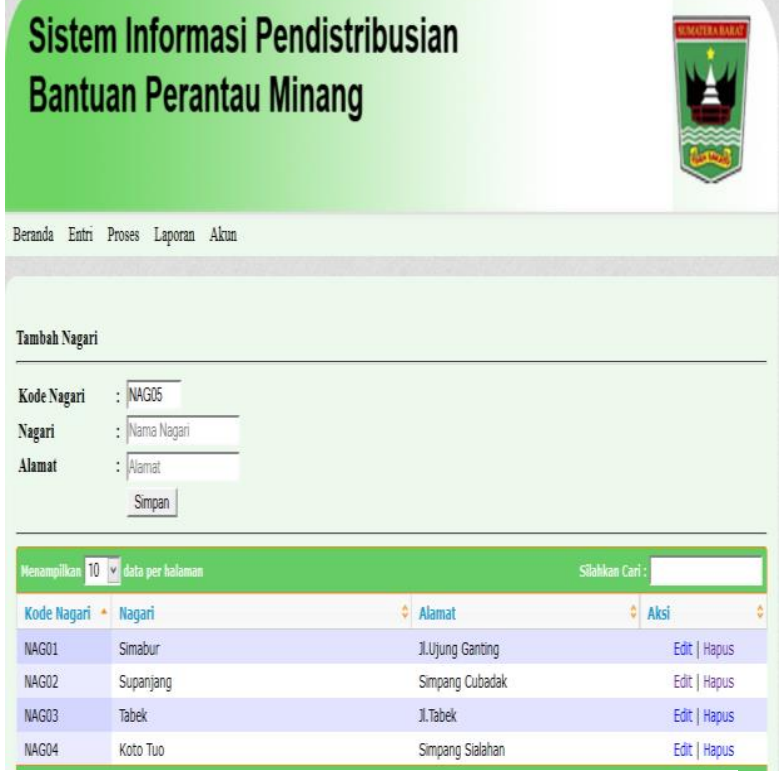

Gambar 8. Form Entri Data Nagari

3) Entri Data Bantuan

Form Entri Data Bantuan berfungsi sebagai sarana untuk menginputkan data bantuan yang diberikan oleh perantau, ditunjukkan pada Gambar 9.

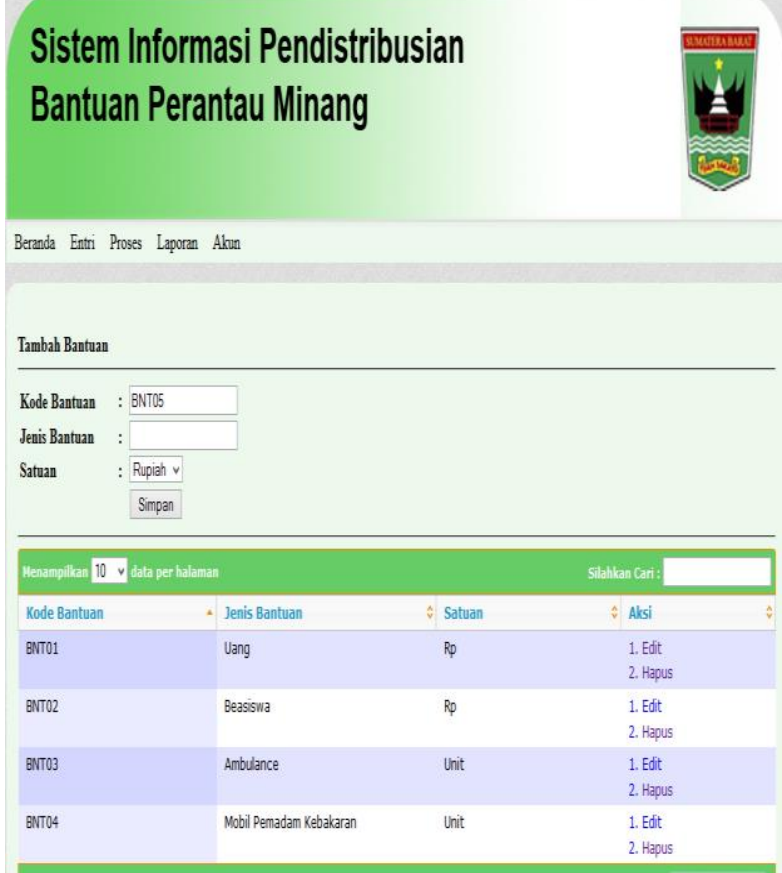

Gambar 9. Form Entri Data Bantuan

4) Entri Data Potensi

Form Entri Data Potensi berfungsi sebagai sarana untuk menginputkan data potensi, ditunjukkan pada Gambar 10. 


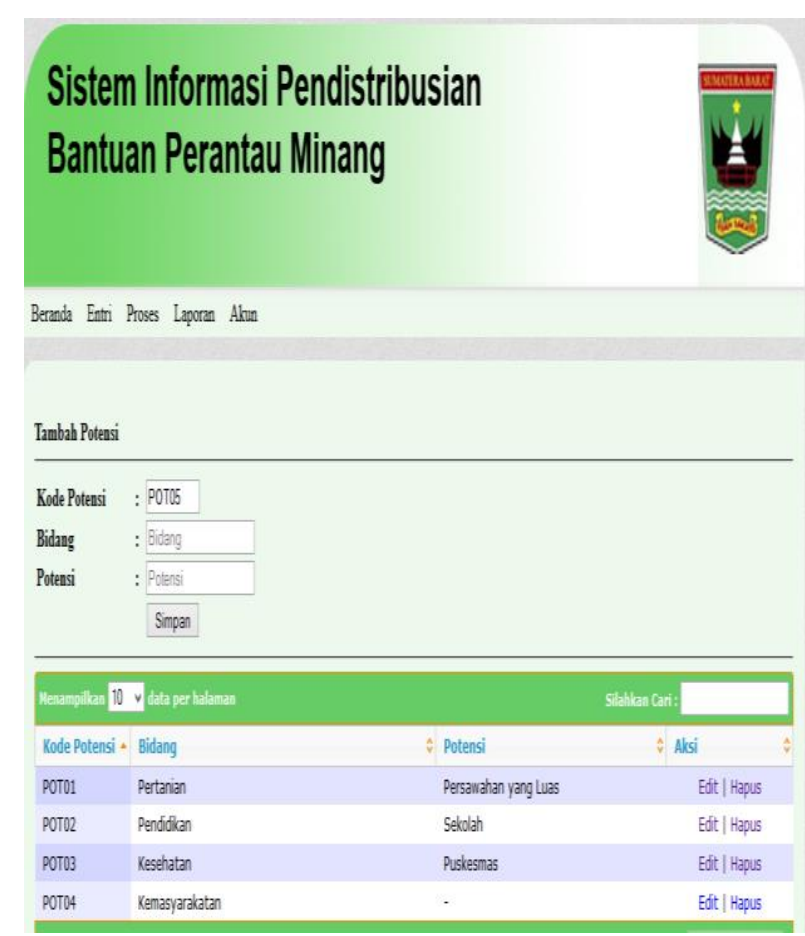

Gambar 10. Form Data Potensi

d. Proses

Menu proses berfungsi untuk memproses pendataan transaksi bantuan, ditunjukkan pada Gambar 11.

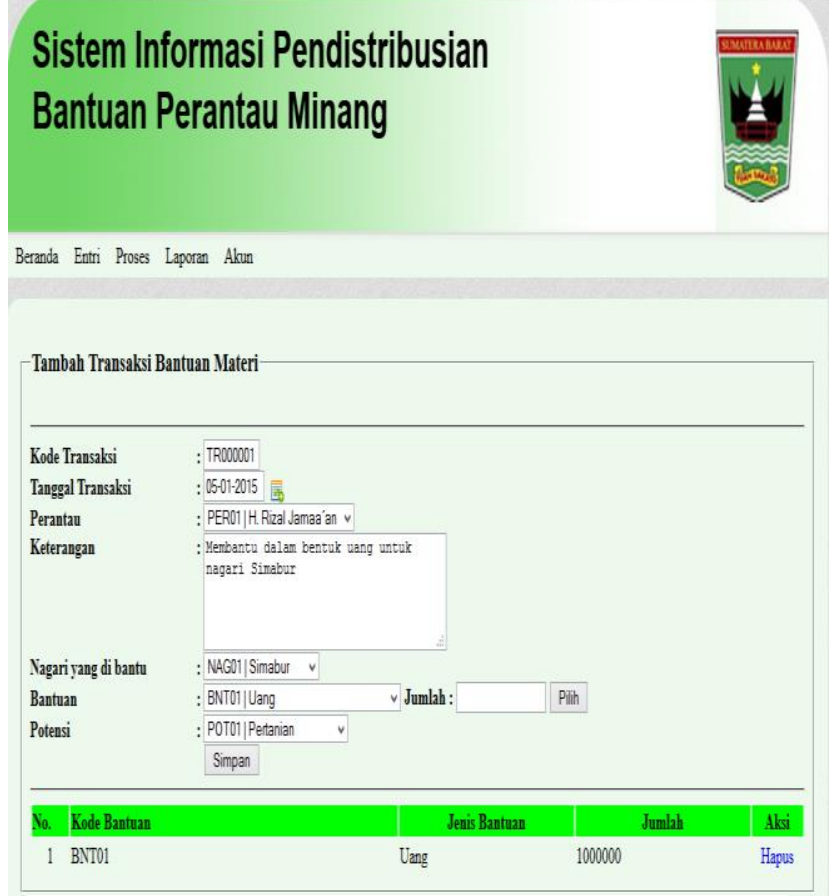

Gambar 11. Proses

e. Laporan

Menu laporan digunakan untuk mencetak laporan atau hasil output dari data yang diproses. Dalam menu laporan terdiri dari 7 laporan:

1) Laporan pendistribusian bantuan perantau Minang per periode bantuan uang (ditunjukkan pada Gambar 12)

2) Laporan pendistribusian bantuan perantau Minang per periode bantuan barang (ditunjukkan pada Gambar 13)

3) Laporan pendistribusian bantuan perantau Minang per nagari bantuan uang (ditunjukkan pada Gambar 14)

4) Laporan pendistribusian bantuan perantau Minang per nagari bantuan barang (ditunjukkan pada Gambar 15)

5) Laporan pendistribusian bantuan berdasarkan nama perantau bantuan uang (ditunjukkan pada Gambar 16)

6) Laporan pendistribusian bantuan berdasarkan nama perantau bantuan barang (ditunjukkan pada Gambar 17)

7) Laporan pendistribusian bantuan perantau Minang secara keseluruhan (ditunjukkan pada Gambar 18).

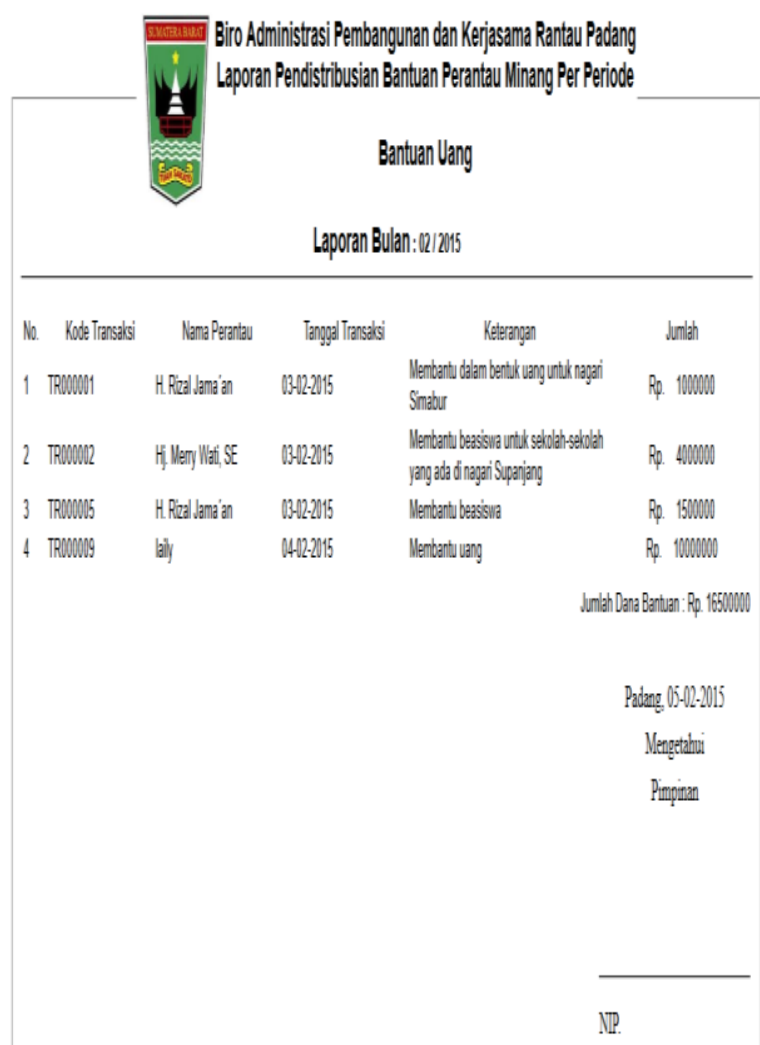

Gambar 12. Laporan Pendistribusian Bantuan Perantau Minang Per Periode Bantuan Uang 


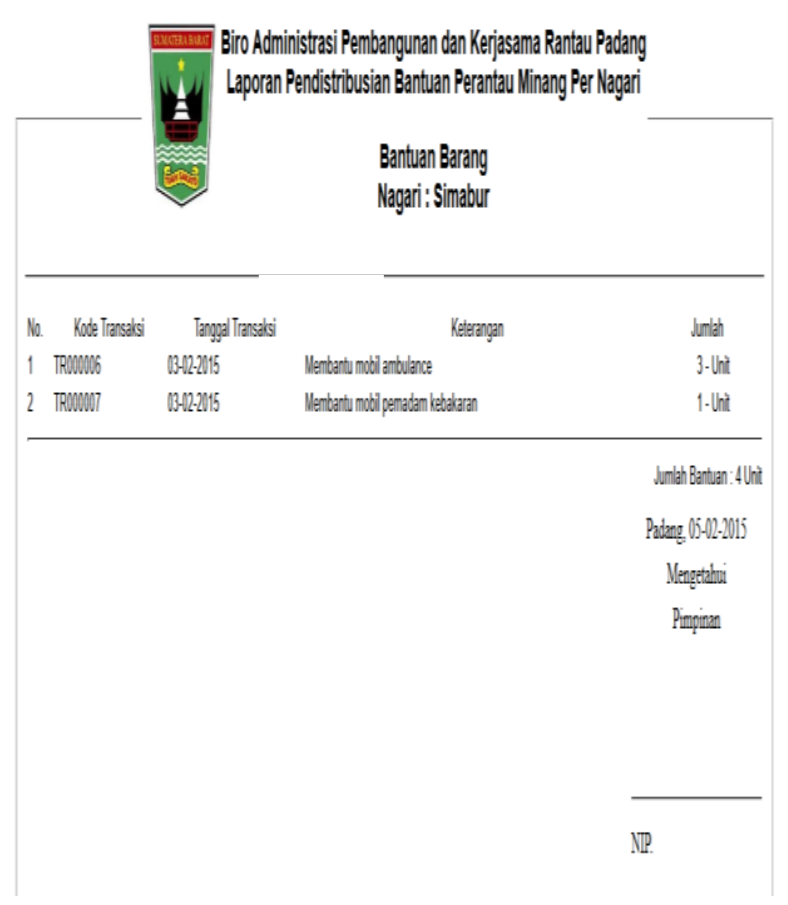

Gambar 13. Laporan Pendistribusian Bantuan Perantau Minang Per Periode Bantuan Barang

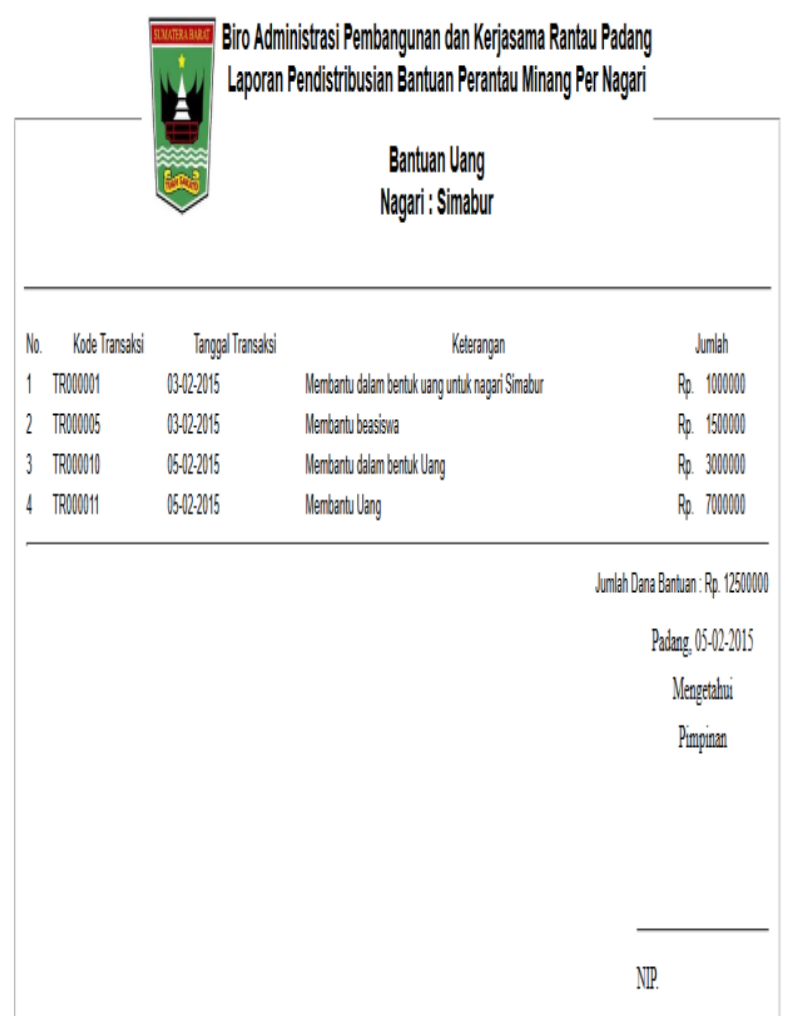

Gambar 14. Laporan Pendistribusian Bantuan Perantau Minang Per Nagari Bantuan Uang
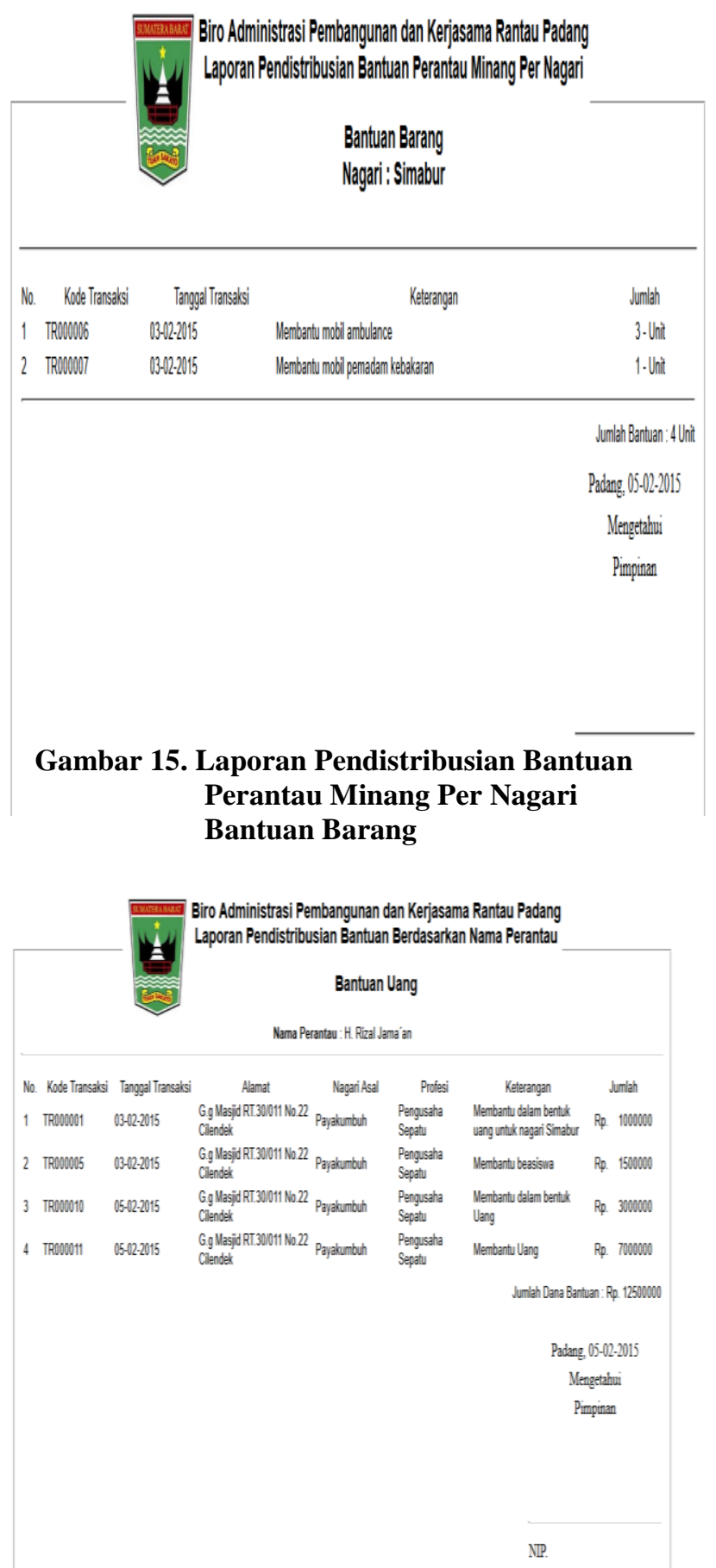

Gambar 16. Laporan Pendistribusian Bantuan Berdasarkan Nama Perantau Bantuan Uang 


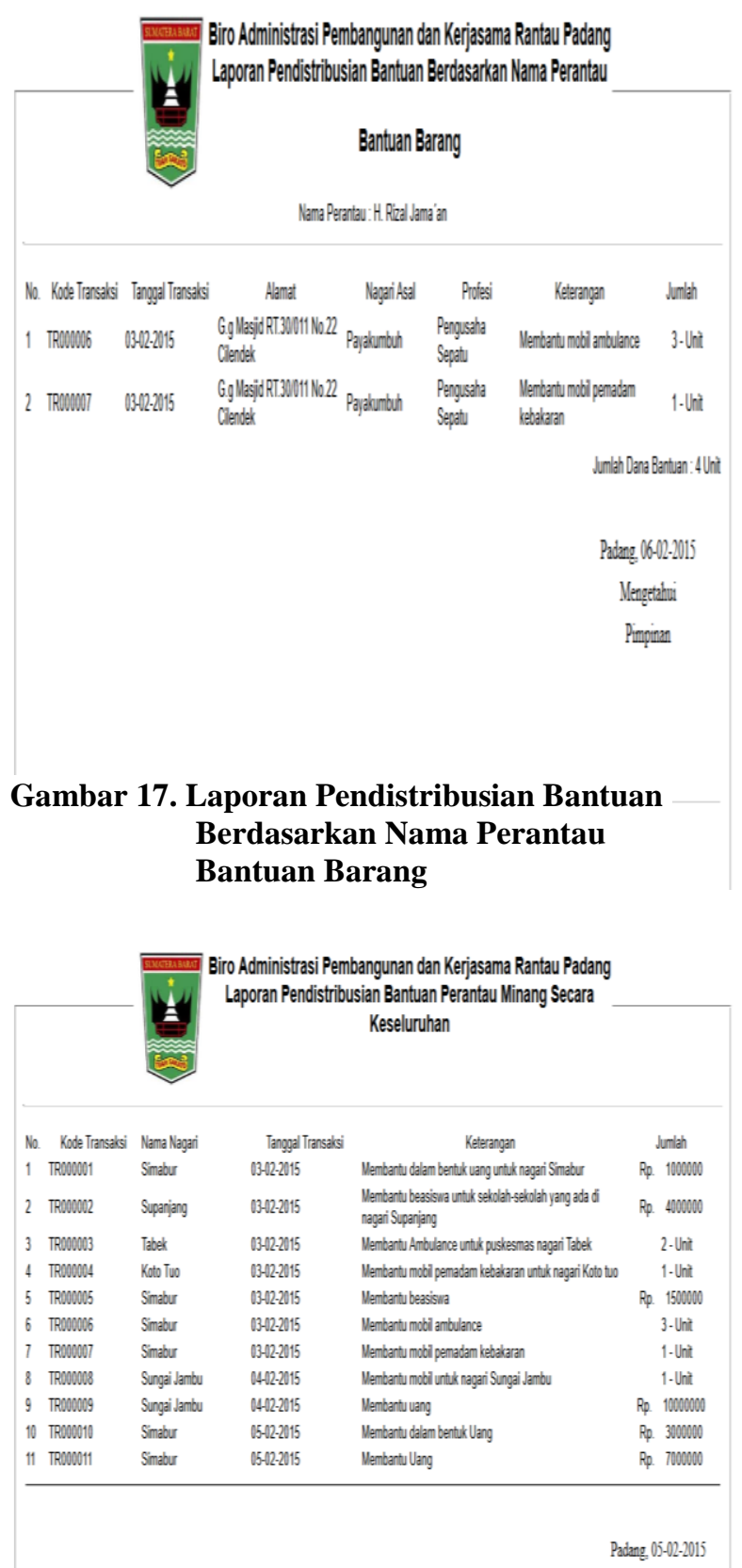

Gambar 18. Laporan Pendistribusian Bantuan thi Perantau Minang Secara Keseluruhan

\section{KESIMPULAN}

Kesimpulan dari penelitian ini sebagai berikut:

a. Pencatatan data pendistribusian bantuan perantau Minang akan lebih cepat dan teratur apabila menerapkan aplikasi Sistem Informasi Pendistribusian Bantuan Perantau Minang di BAPKR karena data pendistribusian bantuan tersebut secara langsung disimpan ke database sehingga tidak perlu lagi dicatatkan di Microsoft Excel.

b. Keamanan data pendistribusian bantuan perantau Minang terjamin karena, data tersebut telah disimpan di dalam database.

c. Pencarian data pendistribusian bantuan perantau Minang akan lebih mudah karena, data dapat dicari berdasarkan indeks.

\section{UCAPAN TERIMAKASIH}

Pada kesempatan ini dan dengan selesainya penyusunan artikel penelitian ini, maka kami sebagai penulis mengucapkan terima kasih kepada Yayasan Amal Bakti Mukmin yang telah memberikan dana dan fasilitas dalam penulisan artikel ini hingga selesai. Selain itu juga kami mengucapkan terima kasih kepada Ketua STMIK Indonesia Padang dan Ketua LPPM STMIK Indonesia Padang yang telah mendorong dan terus memberikan semangat serta motivasi kepada dosen-dosen agar terus maju dan berinovasi dalam melakukan penelitian.

\section{DAFTAR PUSTAKA}

Agung, M. Leo. 2011. Dreamweaver CS5 PHP MySQL untuk Pemula. Andi Offset. Yogyakarta.

Alfatta, Hanif. 2007. Analisis dan Perancangan Sistem Informasi. Andi Offset. Yogyakarta.

HM, Jogiyanto. 2005. Analisis dan Desain Sistem Informasi. Andi Offset. Yogyakarta.

Kadir, Abdul. 2013. Pengenalan Sistem Informasi. Andi Offset. Yogyakarta.

Nugroho, Adi. 2005. Analisis dan Perancangan Sistem Informasi dengan Metodologi Berorientasi Objek. Informatika. Bandung. 